\title{
The Wisdom of e-crowds: Can Masses Create Value?
}

\begin{abstract}
With the rising popularity of the Internet, interactions between companies and their consumers have become more common and meaningful. Researchers often tend to apply the metaphor of community to these on-line networks of $\mathrm{B} 2 \mathrm{C}$ relationships. However, this term implies durability and a long-term orientation. It does not cover more incidental, short-lived groups of consumers, who therefore should not be treated as communities. The purpose of this paper is to explore the ability of these short-term, collective consumer phenomena (addressed as e-crowds within the scope of this paper) to create value. Based on a critical literature analysis that considers works from several different fields of knowledge (including management, economics, psychology and media studies) and empirical examples, we argue that while lacking a complex internal organization, e-crowds are capable of creating use, exchange and sign value when certain conditions are met. However, they are equally likely to perform value-destroying activities, which present real risks for companies that interact with e-crowds.
\end{abstract}

Keywords: crowdsourcing, value creation, crowd, e-crowd, public, consumer behavior JEL:M31, Z13, L14

\section{Introduction}

Approaches to the value creation concept have undergone important revisions in recent years. The advent of the Internet, especially in its 2.0 incarnation, presented two dichotomies - that of company/customer and producer/consumer [Wind, 2006]. Traditionally, these were two ways of describing the same basic flow: that companies create value that customers 
purchase [Humphreys and Grayson, 2008]. Obviously, some exceptions to that relationship did exist. However, before the Internet the means to readily incorporate consumers into the process of value creation was lacking. The Internet, with its interactivity, provided that means by permitting two-way communication, both synchronous and asynchronous, by overcoming physical limitations of space and (partially) time [McQuail, 2007; Szpunar, 2008], and by providing a discrete, modular structure that makes it easier to reconfigure and modify every object mediated by it [Manovich, 2001; Manovich, 2005]. This, in turn, has led to a partial blurring of lines between producers and consumers [Szpunar, 2010]. Thus, a more postmodern approach has been adopted, treating value creation as a process that extends beyond a selected few actors (i.e. companies) and now also involves those who would consume the created value. [Firat, Venkatesh, 1993; Firat, Dholakia, Venkatesh, 1995]. Theoretical concepts supporting this paradigm are numerous - similar ideas can be found in works dealing with service-dominant logic [Vargo, Lusch, 2004], marketing 3.0 [Kotler, Kartajaya, Setiawan, 2010] prosumers [Toffler, 1980], value co-creation [Prahalad, Ramaswamy, 2004] and crowdsourcing [Howe, 2006].

However, when assessing the ability of actors to participate in the value creation process, an additional question is present. Most of the literature attributes the ability to create value either to individuals or organized groups (usually companies or governments, sometimes virtual communities as well), depending on the level of analysis [Lepak, Smith, Taylor, 2007]. Missing is the role of crowds in the Internet - which underlie such concepts as crowdsourcing and crowdfunding. Can they create value? Are they just the sum of their parts (and, in effect, inconsequential to value creation), or are they something more (or perhaps less)? The purpose of this paper is to provide an answer to these questions.

The remainder of the article is organized as follows: the first section introduces the notion of the e-crowd. Different types of value are then discussed, and a framework for analyzing e-crowds' ability to create value established. The third section of the article deals with the ability of e-crowd to create different kinds of value. In the last section we present concluding remarks.

\section{Defining e-crowds}

There are not many definitions of e-crowds in the literature. When it comes to Internet-mediated groups, researchers have instead focused on well-established and long-term oriented collectives like virtual communities [Watson, 1997; McAlexander, Schouten, Koenig, 2002; Valck, van Bruggen, Wierenga, 2009] or tribes [Kozinets, 1999; Cova, Cova, 2002; Mitchel, Imrie, 2011]. According to Russ, e-crowds (or, as he calls them, online crowds) "gather virtually, behave and act collectively and produce effects and phenomena which would not be possible without the Internet" [Russ, 2007, p. 65]. However, he adds 
little to what is already included in the name itself - the definiens does not expand on the definiendum.

Kozinets et. al. treat e-crowds merely as subtype of virtual consumer communities (distinguished from swarms, mobs and hives), characterized by a low concentration of collective innovation, dispersed among a large number of contributors and their intentional collaboration on a particular project [Kozinets, Hemetsberger, Schau, 2008]. While some of these aspects fit the traditional spatial concept of a crowd denoting large gatherings of people in a certain location united by a common cause or idea [Le Bon, 2001; Canetti, 1981], treating e-crowds as a subtype of virtual communities seems problematic because it conflates long-term (and somewhat abstract) phenomenon with short-term and interaction-based ones.

Stage, in defining e-crowds as "the affective unification and relative synchronization of a public in relation to a specific online site" [2013, p. 216], invokes yet another concept of separate collective phenomenon - that is, a public - which was introduced by social psychologist Tarde. According to Tarde within any given public the relationships between participants are not based on physical proximity, but are instead mediated - through the press, telegraph, telephone, etc. [Tarde, 1901]. However, when this concept is applied to the Internet (as in Stage's definition) it may make sense to treat both a public and e-crowds as one. As Arvidsson and Caliandro [2016] noted, the distinction between e-publics and e-crowds can be blurry as both of them are based on mediation rather that face-to-face contacts, and Internet publics can invoke the experience of co-presence that used to be a characteristic unique to crowds. However, e-crowds are far more volatile and short-term oriented than publics, which (even when formed in the Internet) are more stable and attached to the central actor. E-crowds are based more on interactions than relationships, suggesting a spatial, or at least quasi-spatial, character. As noted by Stage, the behavior displayed by groups of Internet users goes beyond a "relatively controlled individual reflecting on the message of the media text" [Stage, 2013, p. 214] that is characteristic to publics, and can instead often take the form of more irrational crowd-like practices. That is why when a piece of Internet content goes viral and all kinds of consumers coming from different backgrounds interact with it - rating it, posting comments, creating modifications or remixes - we are dealing with an e-crowd rather than a public. This the main reason why the distinction between publics and e-crowds is as important as the distinction between e-crowds and virtual communities.

The approach adopted in this paper mirrors the above statements: it is assumed, that e-crowds are entirely separate from other collective phenomena, such as virtual communities, tribes or publics. Whereas it is agreed, that they can serve as a concrete manifestation of a more abstract public or community (expressing themselves and working through e-crowds, just like they can act through individuals or organized teams; hence the aforementioned illusion that Internet publics allow for an experience of co-presence - which in fact stems from one's participation within an e-crowd formed by members of 
a public), they can just as well consist of random, unconnected people, that don't display any sort of affective unification - in other words, e-crowds can be homogenous or heterogeneous. Therefore, in place of the affective unification put forward by Stage as a basis for a crowd creation, a cognitive one is proposed - that is, all participants focus their intentionality (defined as mind's being of or about something [McIntyre, Smith, 1989]) on the same object (while possibly reacting differently to it). Thus, an e-crowd is defined as a group of Internet users finding themselves in the same (virtual) space, and focusing on and interacting with the same piece of content or person. Participation in e-crowds requires attention, and when there is none remaining the e-crowd ceases to exist. In that sense, e-crowds are grounded in the present. Their members are united by sharing the same object of attention and interactions at the same moment in the same vein in which traditional crowds are formed when a group of people share the same space and a similar object of interest. This also gives e-crowds their exclusive character, which in turn gives the illusion of spatiality, making them similar to traditional crowds.

As previously stated, e-crowds can be heterogeneous or homogenous which differentiates them from publics. Tarde observed that people select their press readings according to their individual tastes and then follow those choices, which results in a consistent degree of homogeneity within most publics [Tarde, 1901, p. 24]. Obviously, Internet users make similar decisions (hence the homogenous variant of e-crowds), but when it comes to scouring through the Internet, there is more randomness involved, resulting in more mixed-up groups. Additionally, the Internet culture, including phenomena like flame wars (highly emotional quarrels usually involving lots of cussing) and trolling (making very controversial claims, sometimes bordering on satire, in order to provoke heated arguments) makes Internet users more likely to visit sites or profiles they dislike or disagree with. Hence, the aforementioned heterogeneity and lack of affective unification of some e-crowds, which requires a modification of Stage's definition. It also makes for an interesting trait, possibly affecting e-crowds' ability to create value - whole virtual communities or publics consist mainly of people that share similar opinions, where as members of e-crowds may have nothing in common.

\section{What Does it Mean to Create Value?}

To properly discuss an e-crowd's (or any other type of individual or collective actor) ability to create value, one has to precisely define what value means. Agreeing on certain definitions is especially important where, as here, the term seems self-explanatory but, upon further inspection, possesses a plethora of different meanings in various specialized fields of knowledge. Given the topic of this paper, the concept of value as used in economics shall be utilized. 
A primary reason for the multiple definitions of the value concept is the multitude of actors that seek it. As many researchers [Lepak, Smith, Taylor, 2007; Bowman, Ambrosini, 2010] noted, value means something different to companies, their customers, investors, employees, or even entire societies. It does not suffice to say, that different actors want different things - the very nature of what constitutes value for them differs as well. For companies value means objective and measurable cash flow income. For consumer's, however, value may be something subjective. Vargo and Lusch argued that companies do not really create value for their consumers, but merely a value proposition, and it is up to the consumers themselves to create value based upon a company's offer [Vargo, Lusch, 2008]. In a similar fashion Holbrook argued that for consumers value comes from experience. Within his interactionist approach, value is derived from some objective qualities of a product or service that are to be enjoyed by a consumer, but it remains relative in the sense of being different for different consumers [1996].

There more extreme approaches to this subject, which can be reduced to the opposition between modern and postmodern approaches to goods and their value. The former advocates reducing value to purely the objective qualities of a given product, with value being completely independent of consumer perception, preferences etc. In other words, the higher the quality and the better the parameters, the higher the value. The postmodern approach disregards objective qualities in favor of perception, preferences and narratives created within a given culture and appropriated by consumers themselves [Firat, Venkatesh, 1993]. Even the way the products are used, their functions and utility are subject to consumers' absolute power: for instance, a Starbucks coffee can quench a consumer's thirst, or improve concentration via a caffeine intake, or be the subject of a selfie posted on social media as a part of that consumer's image building strategy (based on cultural meanings attributed to Starbucks). And with changing functions and narratives, value changes as well. The downside of this approach is the obvious difficulty it presents of measuring value. However, even if one agrees with a purely objectivist, modernist approach to consumer value, it still differs in nature to the value as perceived by companies or other types of actors.

These differences in the ways value is created and perceived by different actors within an economic system make it a daunting task to conceptualize any kind of holistic approach to the value creation process that would take into consideration different types of entities. This, in turn, translates directly into challenges to analyzing e-crowds' ability to create value, since this value could be appropriated by both the e-crowd itself or other consumers, as well as a company, whole societies, etc.

One possible way of accommodating different sources and meanings of value is a typology that differentiates between use value and exchange value. The former is constituted by a good's utility, while the latter speaks to the amount of goods (or money) that can be traded for it [Marx, 1904; Marx, 2001]. Based on this distinction Bowman and Ambrosini 
[2010] constructed a map of value flows between a company and other actors, including consumers - which is presented by Figure 1 .

FIGURE 1. Flows of use and exchange value from a company perspective

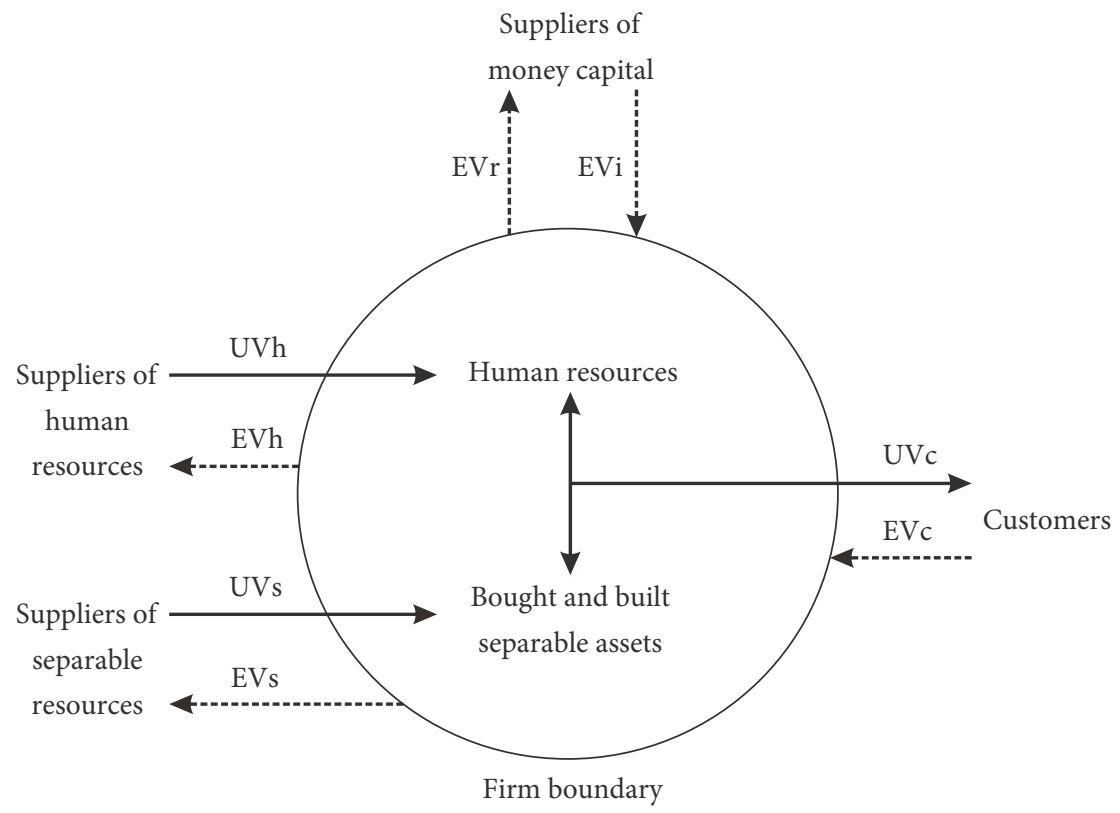

Notes:

flows of exchange value

flows of use value

S o u r ce: Bowman and Ambrosini, 2010.

Bowman and Ambrosini portray the process of value creation and appropriation by assuming that between any given set of two actors there are always two streams of value flowing in opposite directions. A company offers use value for consumers (UVc) in the form of products and services, and consumers supply it with exchange value (EVc) by virtue of paying the price for the product; Suppliers of separable resources (materials, components, machinery, patents, logos, data etc.) and human capital (tasks and services performed) offer utility value (UVs and UVh) to the company (which will combine them further down the line to make products or services of their own) in return for an exchange value in the form of payments from the company. The company and suppliers of capital trade two different flows of exchange value -money invested into the company by suppliers $(\mathrm{EVi})$ and a return on investment flowing from the company to the suppliers (EVr) [Bowman and Ambrosini, 2010]. 
This model has some limitations - it assumes the modernist view of an act of consumption and consumers - in which to consume means only to use up or downright destroy, and never to create. This view, ingrained in marketing by the early works of Kotler [Kotler, Levy, 1969] was challenged by an ever increasing number of publications, with Kotler himself affirming the opposite approach and admitting, that consumers can be producers as well [Kotler, Kartajaya, Setiawan, 2010]. Upon closer examination we find that consumers can serve as suppliers of tangible and human resources (providing information, lending their skills and knowledge, participating in creation of the products etc.) as well as investors (through crowdfunding endeavors).

According to this model consumers receive use value. Although authors admit that every consumer judges use value subjectively, they ultimately define it somewhat objectively as: "properties of products and services that provide utility" [Bowman, Ambrosini, 2010 , p. 480]. However, with the advent of social media, the role of narratives has become more prominent than ever, calling for a more postmodern approach. Thus, we propose another type of value: sign value, as defined by Baudrillard - a value unrelated to the physical properties of a product, which instead stems from the product's signifying socially constructed attributes and concepts such as taste, class and prestige [Baudrillard, 1981].

Taking all the above into consideration, by removing other actors from the equation and focusing on a company-consumer dyadic relation, we can describe the flows of value (Figure 2).

FIGURE 2. Flows of use, exchange and sign value between a company and a consumer

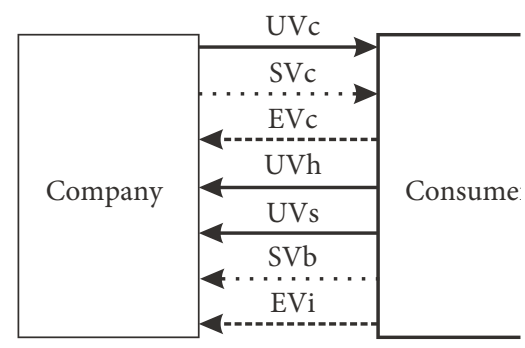

Notes:

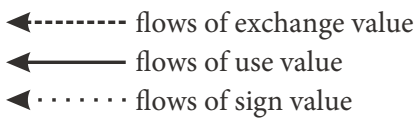

Source: own elaboration.

The core of economical exchange remains the same: a company creates a use value (UVc) for its consumer, who in turn provides exchange value in the form of market price $(\mathrm{EVc})$. However, in addition to use value consumers may receive some sign value (SVc) 
derived from a product's role in consumer image building. At the same time, consumers are capable of creating use value in the form of human inputs (UVh) that often lead to creating separable resources (UVs) - for instance, by participating in crowdsourcing endeavors that will provide resources for the company (like photos, data etc.). Consumers provide companies with sign value for their brands and products (SVb) as well - for instance, by participating in discussions about them, which contributes to building those companies' reputations. Finally, a consumer can invest in a company, providing a stream of exchange value $(\mathrm{EVi})$. It is worth noting that contrary to traditional investors, this consumer does not receive a financial return on investment - rather, the return is the form of use and sign value received.

The outline of value flows between a company and a consumer presented by Figure 2 are our framework for analyzing the ability of e-crowds to create value. It has been established what individual consumers can create value that is then captured by companies. What remains to be seen, is whether participating in e-crowds makes consumers perform in a different way.

\section{Can e-crowds Create Value?}

The idea that e-crowds can create any sort of value may sound controversial. E-crowds are notorious for filling various websites with vitriol, starting countless feuds and arguments, with little to no actual merit [Ilnicki, 2012]. The negative emotions concerning the central subject (the one targeted by users' intentionality) seem to be actually more effective at connecting different users, assuring more longevity for the e-crowd, which would suggest that aggression and hate play a role in e-crowds' very existence. More importantly, portraying crowds as a purely destructive phenomenon is an established and long lasting trope in western culture. Crowds tend to feature as one side of discrete dichotomy, and are usually opposed by a brilliant individual, serving as a foil to him and his endeavors - that is, a conservative mass that halts any kind of progress, rather than fostering it. This view of crowds has been reiterated throughout history by a multitude of thinkers. Nietzsche claimed that "madness is rare in the individual - but with groups, parties, peoples, and ages it is the rule" [Nietzsche, 1997, p. 103]. According to another philosopher, Kierkegaard, "crowd is untruth", and "truth always rests with the minority" [Kierkegaard, 1847]. Bauman paraphrased Seneca, saying "avoid the crowd, avoid mass audiences, keep your own counsel, which is the counsel of philosophy - of wisdom you can acquire and make your own" [Bauman, 2008, p. 34]. This approach made its way into popular culture. Most notably, one of the best known quotes from Pratchett claims that "the intelligence of the creature known as a crowd, is the square root of the number of people in it" [Pratchett, 1998, p. 436]. 
Those sentiments were echoed by early crowd psychology. Le Bon, regarded as a father to this field of knowledge, considered crowds as a pathology causing human beings to degenerate intellectually and become possessed by primitive instincts and emotions forming so called group mind. He did, however, acknowledge that crowds - though incapable of creation and with a destructive modus operandi - do sometimes serve a positive purpose - overthrowing oppressive regimes, for instance [Le Bon, 2001, pp. 13-19]. A similar stance on the subject of crowds was presented by other psychologists, Allport [1924, pp. 295-312] and Jung [2015, p. 226].

In modern psychology the crowd usually is not treated as a pathology. For example according to Reicher any instance of crowd aggression should be attributed to the shared values and goals of its participants and their common social identity, rather than to some intrinsic traits of crowds as collective phenomena [Reicher, 2001, p. 194]. However, while Reicher cleansed crowds of their supposed pathological and purely irrational character, it does not necessarily mean that crowds are capable of creating value - especially for companies.

One author who does consider crowds able to create value (with a focus on knowledge) was Surowiecki. Based on multiple examples of crowds' problem solving (from estimating the weight of livestock, and precisely determining the location of a lost submarine, to the institution of the free market itself), he concluded that groups of unassociated people, taken as a whole are more competent than gifted individuals [Surowiecki, 2007, p. 22]. He used the metaphor of an ant colony, within which no individual ant possesses all the information, but taken together as a whole the colony is able to solve problems efficiently.

However, according to Surowiecki three conditions have to be meet, in order to unlock the wisdom of crowds: diversity, independence, and decentralization. Diversity is met when people forming the crowd come from different backgrounds - be it professional, cultural, etc. Independence pertains to a lack of informational cascades in the form of popular opinions, shared misconceptions etc. that skew crowd members' perceptions. Last but not least, there is the requirement of decentralization. According to Surowiecki, when there is an overabundance of formalities, rigid structures and procedures, the insights of individual crowd members tend to be overlooked, and the collective wisdom cannot be reached [pp. 23-83].

Now, let's examine how those e-crowds fare against the criteria for unlocking collective wisdom of the crowds laid down by Surowiecki. The level of diversity differs from e-crowd to e-crowd. However, the Internet as a medium does not diminish the chances of a crowd being diverse. Obviously, some websites or Internet celebrities tend to attract one group of people over others, be it through conscious decisions of consumers or content algorithms based on a person's preference and viewing behavior history. However, that is the case for physical crowds as well - some of them can be homogenous (like those partaking in organized strikes), while others may largely consist of random passers-by. 
The independence of e-crowd members is complicated. To an extent it is a function of diversity. Participants coming from different backgrounds are less likely to share the same information sources and are less prone to information cascades. Some researchers consider the popularity of social media a threat to the independence of opinions, since they tend to limit users' interactions to a closed circle of friends, which hinders the free flow of information and makes it more likely for certain opinions and statements to be repeated uncritically. Surowiecki himself raised this concern when talking about Internet crowds: "One of the fundamental characteristics of a network is that, once you are linked in the network, the network starts to shape your views and starts to shape your interactions with everybody else. That's one of the things that defines what a network is" [Surowiecki, 2005]. One of the key characteristics of Internet communication, the usage of memes, threatens the independence of thought within any e-crowd. Words, pictures, ideas, can all go viral, be spread everywhere (even transcending the Internet itself and making their way to unmediated, face-to-face communication) and shape how people think about different subjects. This causes communication within e-crowds to resemble a closed loop, where the same content is recycled and posted over and over again (discussion boards like 4chan are a good example of this). At the same time, however, the Internet improves access to all kinds of information and other resources. While many users prefer to submit to communicational schemes provided by memes [Ilnicki, 2011], there's still a possibility of actual in-depth research involving different sources. In that sense, the Internet can extend the human mind [Clark, 2003], allowing e-crowd members to literally stand and build on the shoulders of giants. This brings us to the last point on Surowiecki's checklist.

The structure of the Internet under the web 2.0 paradigm fits the bottom-up logic required to unlock the wisdom of crowds perfectly. It supplies users with the tools to express themselves, and makes it easier for them to actually be heard. The Internet serves as the infrastructure that Surowiecki spoke about - it is not centralized enough to let certain biases completely dominate the creation process and obstruct creativity and diversity, while making it possible to avoid complete anarchy and to aggregate inputs from different users.

This tells us that (at least in theory) e-crowds should be able to create value for companies. But do they in fact? Let's start with the subject of use value. One might think that the phenomenon known as crowdsourcing, in which a company literally outsources certain tasks to the crowd - usually in form of an open call over the Internet [Howe, 2006; Kleemann, Voß, Rieder, 2008] - is proof of that possibility. There is a distinction to be made, however. Many crowdsourcing projects do not fully utilize the abilities of e-crowds. For example, online stores selling clothes designed by consumers (or, more precisely: prosumers) themselves; It would seem that an e-crowd creates use value for products sold, but in reality it is just individual consumers, who happen to be part of a certain e-crowd, which in itself is not a source of use value - at least not the use value of separable resources. One could take away all the other people from the website and it would not diminish the one remaining individual's ability to design clothes - the end product would remain the 
same. The use value created by the e-crowd taken as a whole would be equal to the sum of the values independently created by each individual constituting it. There is no synergy and no synthesis in this case.

However, e-crowds in such a case do provide a medium through which a company can meet these talented individuals. Because the e-crowd rates creations of different prosumers, it makes those that fit their tastes more visible to the company, which can reach them and make use of their skills - either in form of company - consumer value co-creation or by employing said consumer. In that sense, e-crowds provide a different type of use value - the one connected with human resources.

A company can also tap into an e-crowd's potential by encouraging its members to share their product insights, remix it, post their own iterations of the original, or simply rate it. Introducing such feedback loops allows companies to use tacit information possessed by different e-crowd members to create things beyond the reach of an individual, or sum of individuals. For instance, this has been used for video games dubbed "wiki games" (their list includes such titles as Minecraft, Don't Starve, Terraria). They have in common an unusually high level of complexity, which makes them almost unplayable without external knowledge sources that becomes integral to the overall experience. Consumers playing those games create Internet encyclopedias (wikis), which they then use to share knowledge and insights. Every aspect of such a game is the subject of discussion by multiple players, with different experiences. Good ideas are elaborated upon, whereas bad ones are filtered out. These wikis in turn help shape the experience of newer generations of players. This is clearly a case of consumer e-crowds providing value in form of human inputs and also creating separable resource use value (a wiki in this case). That value is then returned to them by a better use value of the product they consume.

Similarly, there are some services that heavily rely upon real-time interactions within e-crowds for value creation. A streaming service like twitch.tv, which allows people to create live broadcasts of whatever they please - such as playing games, creating art, having a conversation - possesses a chat feature, which allows viewers to interact with the owner of the channel as well as the rest of the audience. This chat box is an integral part of the livestream watching experience. Even though more often than not it is filled with memes, emojis, and many aggressive and/or insensitive remarks, it still remains very popular among twitch.tv users. In fact, its importance is such that multiple features based around it have been introduced by twitch.tv itself and by external producers. Some games meant to be played by livestreamers allow additional interactions between the streamer and his audience. For instance, in a game called Party Hard viewers can vote for additional in-game events, making it easier or harder (usually the latter) for a streamer to complete the level.

Thus, e-crowds can collectively create a use value of a commodity. As Humphreys and Grayson [2008] noted, this can hardly be considered revolutionary, since consumption often involves creating a use value (e.g, assembling IKEA furniture, making tea, etc.). However, the cases described above are different in that the use value created can be enjoyed by 
every consumer (because it has been incorporated into a product itself), not just a single one. Such products present a better value proposition that can raise their market price. In that sense, e-crowds can increase the already existing flows of exchange value by actively and purposefully helping companies be more successful on the market.

E-crowds can also provide exchange value in the form of investment. This is particularly evident in the case of livestreamers. During streaming sessions e-crowd audience members often support the streamer with small donations, usually in exchange for the donator having his attached message read aloud by the streamer or a voice synthesizer. This leads to individual e-crowd members eliciting reactions by other participants, resulting in more donations.

Finally, a value that e-crowds create is narration. Whenever people share experiences with a product or a brand, or participate in interactions based around them, they help create a certain story [Fog, Budtz, Munch et al., 2011]. Those stories, in turn, constitute a socially constructed sign value. For instance, Apple's brand narrative for individuals, artists and professionals is as much a creation of e-crowds as it is the company's. Since the marketing process of positioning takes place in consumer minds [Ries, Trout, 2001], consumers can wrestle control over it. E-crowds that support company proposed narratives strengthen its products' sign value (by, for example, advocating for its products during Internet discussions).

There is, however, also the danger of e-crowds performing activities that destroy value, instead of creating it. In the case of companies, that would usually entail things like inefficiencies of mismanagement [Bowman, Ambrosini 2010]. E-crowds, on the other hand, may manifest a wider range of value destroying activities. For instance, the Internet trolling culture can frustrate company attempts at crowdsourcing. This was the case with McDonald's and its "Create Your Taste" tool that allowed consumers to customize their own burgers from a list of different products and toppings, as well as vote for their favorite designs. However, consumers had other ideas. Not only did they compose and vote for absurd creations like burgers consisting exclusively of lettuce, but they also presented a multitude of burgers with not very marketable, or downright inappropriate names (e.g., "atheist delight" - having no ingredients, "the carbonator" being only multiple bread roll layers, and the "Bernie socialist feast," consisting of a single bun with no topping) [McGarry, 2016]. This initiative, which has been aborted by McDonald's, wasted time and resources, and made the company seem detached from realities of the Internet - an example of e-crowd destroying value.

This may have been a lack of independence within the e-crowd due to spread of a meme, leading the e-crowd to ruin McDonald's efforts. However, even when no trolls sabotage company attempts to crowd source the problem persists, since similar endeavors are prone to all kinds of manipulation. Contests decided by voting are notorious for turning into popularity contests in which the number of friends, rather than product quality, is the deciding factor (assuming no cheaters with thousands of fake accounts at their disposal 
participating in vote exchange systems). That is why an additional requirement for unlocking the collective wisdom of e-crowds - participant sincerity and good will - is needed. This can be encouraged by rewarding participants who voted for the eventual winner, which promotes selecting projects that have the greatest chances of success [Wieczerzycki, 2015].

Another example of e-crowds destroying value is the recent case of Tay, a twitter bot introduced by Microsoft. It was an artificial intelligence intended to learn from interactions with human users of this social medium. It did not take long for e-crowds of twitter users to turn this bot into a bigoted racist voicing a deep appreciation for Adolf Hitler. Microsoft had to pull Tay down soon after its debut [Price, 2016].

E-crowds can easily destroy sign value as well. Consumer narratives, which are inherently uncontrollable by companies, can easily steer the product's image away from what was originally intended in a way that is undesirable from the company's point of view. For every e-crowd preaching Apple's greatness, there is another one forming narratives that present Apple's products as overpriced and its users as pretentious snobs.

Plainly, e-crowds can both improve the image of a product or destroy it.

\section{Conclusions}

As discussed above, e-crowds can create value, which can be of both a use and an exchange character, as well as sign-based. E-crowds can help create products, participate in the process of decision making, serve as a source of human capital, and contribute to brand- or product-related narratives. However, certain conditions are needed to tap into their collective wisdom. E-crowds are able to meet the criteria outlined by Surowiecki (diversity, independence and decentralization), but also need to possess good will and be sincere in their efforts. That is, they must refrain from trolling or cheating - which can come naturally, if the e-crowd is passionate about the task performed, or it can be facilitated by encouragement by the company.

A limitation of this study is it shows e-crowds can create value but does not address whether it is actually worthwhile for companies to purposefully include e-crowds into the value creation process. Considering the risks involved, it might be better for a company to uphold the traditional divide between consumers and producers. To properly address that question future studies should move beyond the existing literature and conduct empirical research - perhaps by comparing the performance of companies that do, and do not, engage e-crowds in their value creation process.

The unavoidable danger posed by e-crowds is their tendency to be aggressive, highly volatile and susceptible to stories, images or memes that can lead to performing activities that destroy rather than create value. It requires real analysis, tact, and situational awareness from companies to minimize these dangers. 


\section{Notes}

1 Author’s e-mail address: marcin.wieczerzycki@ue.poznan.pl

\section{References}

Allport, F.H. (1924), Social Psychology, Boston, Houghton Mifflin.

Arvidsson, A., Caliandro, A. (2016), Brand Public, Journal of Consumer Research, Vol. 42, No. 5, pp. 727-748.

Baudrillard, J. (1981), For a critique of the political economy of the sign, trans. C. Levin, Telos Press Publishing, St. Louis, MO.

Bauman, Z. (2008), The art of life, Polity Press, Cambridge.

Bowman, C., Ambrosini, V. (2010), How value is created, captured and destroyed, European Business Review, Vol. 22, No. 5, pp. 479-495.

Canetti, E. (1981), Crowds and power, Continuum, New York.

Clark, A. (2003), Natural-Born Cyborgs. Minds, Technologies, and the Future of Human Intelligence, Oxford University Press, Oxford.

Cova, B., Cova, V. (2002), Tribal marketing, European Journal of Marketing, Vol. 36, No. 5/6, pp. 595-620.

Firat, A.F., Dholakia, N., Venkatesh, A. (1995), Marketing in a postmodern world, European Journal of Marketing, Vol. 29, No. 1, pp. 40-56.

Firat, A.F., Venkatesh, A. (1993), Postmodernity: the age of marketing, International Journal of Research in Marketing, Vol. 10, No. 3, pp. 227-249.

Fog, K., Budtz, C., Munch, P., Blanchette, S. (2011), Storytelling. Narracja w reklamie i biznesie, trans. J. Wasilewski, B. Brach, Saatchi \& Saatchi, Warszawa.

Holbrook, M.B. (1996), Special Session Summary Customer Value C a Framework For Analysis and Research, in: K.P. Corfman, J,G. Lynch, Jr. (eds.), NA - Advances in Consumer Research Volume 23, Association for Consumer Research, Provo, UT, pp. 138-142.

Howe, J. (2006), The Rise of Crowdsourcing, Wired, No. 14.06, available at: http://archive.wired. com/wired/archive/14.06/crowds.html.

Humphreys, A., Grayson, K. (2008), The Intersecting Roles of Consumer and Producer. A Critical Perspective on Co-production, Co-creation and Prosumption, Sociology Compass, Vol. 2, No. 3, pp. 963-980.

Ilnicki, R. (2011), Dziecinnienie języka. Dewastacja logosu w elektronicznych dyskursach, Studia Kulturoznawcze, No. 1, pp. 59-67.

Jung, C.G. (2015), Collected Works of C.G. Jung: The First Complete English Edition of the Works of C.G. Jung, Taylor \& Francis, New York.

Kierkegaard, S. (1847), Crowd is Untruth. On the Dedication to “That Single Individual”, available at: http://www. ccel.org/ccel/kierkegaard/untruth/files/untruth.html

Kleemann, F., Voß, G.G., Rieder, K. (2008), Un (der) paid Innovators: The Commercial Utiliza-tion of Consumer Work through Crowdsourcing, Science, Technology\& Innovation Studies, Vol. 4, No. 1, pp. 5-26.

Kotler, P., Kartajaya, H., Setiawan, I. (2010), Marketing 3.0: From Products to Customers to the Human Spirit, John Wiley \& Sons Inc., Hoboken.

Kotler, P., Levy, S.J. (1969), Broadening the Concept of Marketing, Journal of Marketing, Vol. 33, No. 1, pp. 10-15. 
Kozinets, R.V. (1999), E-tribalized marketing?: the strategic implications of virtual communities of consumption, European Management Journal, Vol. 17, No. 3, pp. 252-264.

Kozinets, R.V., Hemetsberger, A., Schau, H.J. (2008), The Wisdom of Consumer Crowds: Collective Innovation in the Age of Networked Marketing, Journal of Macromarketing, Vol. 28, No. 4, pp. 339-354.

Le Bon, G. (2001), The Crowd. A Study of the Popular Mind, Batoche Books, Kitchener.

Lepak, D.P., Smith, K.G., Taylor, S.M. (2007), Introduction to Special Topic Forum: Value Creation and Value Capture: A Multilevel Perspective, The Academy of Management Review, Vol. 32, No. 1, pp. 180-194.

Manovich, L. (2001), The Language of New Media, MIT Press, Cambridge.

Manovich, L. (2005), Remixability and Modularity, available at: http://manovich.net/index.php/projects/remixability-and-modularity

Marx, K. (1904), A contribution to the critique of political economy, trans. N.I. Stone, International Publishers, New York.

Marx, K. (2001), Capital: A critique of political economy, trans. B. Fowkes and D. Fernbach, Penguin Books in association with New Left Review, New York.

McAlexander, J.H., Schouten, J.W., Koenig, H.F. (2002), Building Brand Community, Journal of Marketing, Vol. 66, No. 1, pp. 38-54.

McGarry, J. (2016), McDonald's let the internet design burgers and regretted it immediately, Mashable, No. 21.07, available at: http://mashable.com/2016/07/21/mcdonalds-burger-design-goes-wrong/

McIntyre, R., Smith, D.W. (1989), Theory of Intentionality, in: J.N. Mohanty, W.R. McKenna (eds.), Husserl's phenomenology. A textbook, Center for Advanced Research in Phenomenology; University Press of America, Washington, D.C., pp. 147-179.

McQuail, D. (2007), Teoria komunikowania masowego, trans. A. Szulżycka and M. Bucholc, Wydawnictwo Naukowe PWN, Warszawa.

Mitchell, C., Imrie, B.C. (2011), Consumer tribes: membership, consumption and building loyalty, Asia Pacific Journal of Marketing and Logistics, Vol. 23, No. 1, pp. 39-56.

Nietzsche, F.W. (1997), Beyond good and evil. Prelude to a philosophy of the future, Dover Publications, New York.

Prahalad, C.K., Ramaswamy, V. (2004), Co-creating unique value with customers, Strategy $ఓ L e a d e r s h i p$, Vol. 32, No. 3, pp. 4-9.

Pratchett, T. (1998), Jingo, Corgi Books, London.

Price, R. (2016), Microsoft is deleting its AI chatbot's incredibly racist tweets, Business Insider, No. 24.03, available at: http://www.businessinsider.com/microsoft-deletes-racist-genocidal-tweets-from-ai-chatbot-tay-2016-3? IR=T

Reicher, S. (2001), The Psychology of Crowd Dynamics, in: M.A. Hogg, R.S. Tindale (eds.), Blackwell handbook of social psychology: Group processes, $1^{\text {st }}$ edition., Blackwell Publishers, Malden, pp. 182-208.

Ries, A., Trout, J. (2001), Positioning. The battle for your mind, McGraw-Hill, New York, London.

Russ, C. (2007), Online Crowds - Extraordinary Mass Behavior on the Internet, I-MEDIA '07 and I-SEMANTICS '07 conferences, available at: http://papers.ssrn.com/sol3/papers.cfm?abstract_id=1620803

Stage, C. (2013), The online crowd: a contradiction in terms? On the potentials of Gustave Le Bon's crowd psychology in an analysis of affective blogging, Distinktion: Scandinavian Journal of Social Theory, Vol. 14, No. 2, pp. 211-226.

Surowiecki, J. (2005), The power and the danger of online crowds, TED2005 conference, Monterey, available at: http://www.ted.com/talks/james_surowiecki_on_the_turning_point_for_social_media/transcript?language=en Surowiecki, J. (2007), Wisdom of the Crowds, Anchor Books, New York. 
Szpunar, M. (2008), Redefinicja pojęcia czasu i przestrzeni w dobie Internetu, in: M. Sokołowski (ed.), Kulturowe kody mediów, Adam Marszałek, Toruń, pp. 59-73.

Szpunar, M. (2010), Nowe media a paradygmat kultury uczestnictwa, in: M. Graszewicz, J. Jastrzębski (eds.), Teorie komunikacji i mediów 2, Atut, Oficyna Wydawnicza, Wrocław, pp. 251-262.

Tarde, G. (1901), L'opinion et la foule, Presses Universitaires de France, Paris.

Toffler, A. (1980), The third wave, Bantam Books, New York.

Valck, K. de, van Bruggen, G.H., Wierenga, B. (2009), Virtual communities: A marketing perspective, Decision Support Systems, Vol. 47, No. 3, pp. 185-203.

Vargo, S.L., Lusch, R.F. (2004), Evolving to a New Dominant Logic for Marketing, Journal of Marketing, Vol. 68, No. 1, pp. 1-17.

Vargo, S.L., Lusch, R.F. (2008), Service-dominant logic: continuing the evolution, Journal of the Academy of Marketing Science, Vol. 36, No. 1, pp. 1-10.

Watson, N. (1997), Why we argue about virtual community: a case study of the Phish.net fan community, in: S. Jones (ed.), Virtual culture. Identity and communication in cybersociety, Sage Publications, London, pp. 102-132. Wieczerzycki, M. (2015), Tłum internetowy jako sieć relacji na rynku B2C, Organizacja i Kierowanie, Vol. 167, No. 2, pp. 75-90.

Wind, Y. (2006), Blurring the lines: is there a need to rethink industrial marketing?, Journal of Business \& Industrial Marketing, Vol. 21, No. 7, pp. 474-481. 